\title{
АНАЛІЗ НОРМАТИВНИХ ВИМОГ ЩОДО РЕГЛАМЕНТАЦІЇ ЗАСТОСУВАННЯ РЕСУРСІВ ТА ГІДРОТЕХНІЧНИХ СПОРУД МАЛОЇ ГІДРОЕНЕРГЕТИКИ ДЛЯ ОБ'ЄКТІВ СОЦІАЛЬНОЇ СФЕРИ
}

\author{
А.П. Вербовий, канд. техн. наук \\ Інститут відновлюваної енергетики НАН України, \\ 02094, вул. Гната Хоткевича, 20А, м. Київ, Україна.
}

В наш час відновлення інтересу до малої гідроенергетики викликано невпинним зростанням тарифів на електроенергію, скороченням будівництва великих гідро- та гідроакумулювальних станиій (ГЕС, ГАЕС), значним підвищенням цін на органічне паливо та наявністю малоефективних дизельних електростанцій у віддалених населених пунктах. Подальший розвиток малоі гідроенергетики неможливий без скоординованої державою схеми розміщення малих ГЕС, розробки процедур землевідведення, дозволів на спеціальне водокористування, налагодження співпраці з громадськими організаціями екологічного та природоохоронного спрямування, оновлення нормативної бази. Чинна нормативна база не сприяє розвитку малої гідроенергетики, оскільки для виконання проєкту малих ГЕС (ГАЕС) необхідно затвердити таку саму кількість нормативної документації та висвітлити ті самі питання, щзо й для будівництва великої ГЕС (ГАЕС). Реформування потребує існуюча нормативно-технічна база проєктування, будівництва та експлуатації ГЕС та ГАЕС. У статті розглянуто й проаналізовано такі нормативні документи: Водний кодекс Украйни, Правила влаштування електроустановок, галузеві керівні документи (34.20.507-2003. Технічна експлуатація електричних станцій і мереж. Правила. 34.03.106-2003. Безпека гідротехнічних споруд і гідротехнічного обладнання електростанцій Украӥни. Положення про галузеву систему нагляду). Розглянуто основні положення, щодо проєктування, будівнищтва та експлуатації ГЕС; регулювання правових відносин з метою забезпечення збереження, науково обтрунтованого раціонального використання вод для потреб населення i галузей економіки, відтворення водних ресурсів, охорони вод від забруднення, засмічення та вичерпання, запобігання шкідливим діям вод та ліквідаиії їх наслідків, поліпшення стану водних об'єктів, а також охорони прав підприємств, установ, організацій і громадян на водокористування. Аналіз полегшує прочедуру розгляду і моніторингу законодавчої бази, сприяє підвищенню ефективності роботи експертів, інженерів, науковиів, а також якості прийнятих законів у цілому. Бібл. 13. Ключові слова: нормативна база, документ, вода, гідроелектростанція, гідроакумулювальна електростанція.

\section{ANALYSIS OF LEGISLATIVE REQUIREMENTS REGULATING THE USE OF RESOURCES AND HYDROTECHNICAL STRUCTURES IN SOCIAL SPHERE FACILITIES}

A. Verbovij, candidate of technical science

Institute of Renewable Energy of the National Academy of Sciences of Ukraine, 02094, 20A Hnata Khotkevycha St., Kyiv, Ukraine.

Currently, the recovery of interest in small hydropower is caused by the steady increase in electricity tariffs, reduced construction of large hydro and hydro storage plants (HPP, PSH), a significant increase in fossil fuel prices and the presence of inefficient diesel power plants in remote areas. Further development of small hydropower is impossible without a state-coordinated scheme of small hydropower plants, development of land disposal procedures, permits for special water use, cooperation with environmental and environmental organizations, updating the regulatory framework. The existing regulatory framework does not promote the development of small hydropower, as for the implementation of the project of small hydropower plants it is necessary to approve the same amount of regulatory documentation and cover the same issues as for the construction of large hydropower plants. The existing normative and technical base of design, construction and operation of HPP and PSH needs to be reformed. The following normative documents are considered and analyzed in the article: Water Code of Ukraine, Rules of electrical installations, branch guiding documents (34.20.507-2003. Rules 34.03.106-2003 Safety of hydraulic structures and hydraulic equipment of power plants of Ukraine (Regulations on the branch system of supervision). The main provisions concerning: design, construction and operation of HPPs are considered; regulation of legal relations in order to ensure the preservation, scientifically sound, rational use of water for the needs of the population and industries, reproduction of water resources, protection of water from pollution, clogging and depletion, prevention of harmful effects of water and elimination of their consequences, improving water bodies, as well as protection of the rights of enterprises, institutions, organizations and citizens to water use. The analysis facilitates the procedure of consideration and monitoring of the legal framework, helps to increase the efficiency of experts, engineers, scientists and the quality of adopted laws in general. Ref. 13.

Keywords: regulatory framework, document, water, hydroelectric power plant, pumped storage hydro station. 


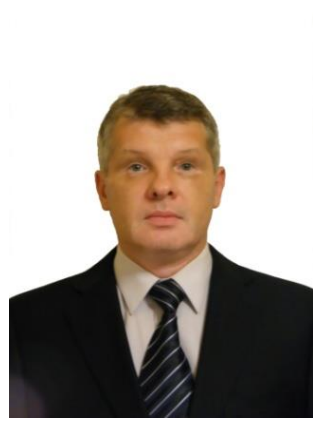

А.П. Вербовий

A. Verbovij
Відомості про автора: старший науковий співробітник відділу гідроенергетики Інституту відновлюваної енергетики НАН України

Освіта: Національний технічний університет України «Київський політехнічний інститут імені Ігоря Сікорського». Спеціальність: «Електропривод та автоматизація промислових установок»

Наукова сфера: відновлювані джерела, гідроелектростанція, мала гідроенергетика Публікації: 129

ORCID: 0000-0003-2838-6032

Контакти: тел./факс: +38(044)206-28-09 e-mail: hydro@ive.org.ua
Author information: Senior Research of Hydropower Engineering Department, Institute of Renewable Energy NAS of Ukraine Education: Natiwnal Technical University of Ukraine «Igor Sikorsky Kyiv Polytechnic Institute». Specialty: "Electric drive and automation of industrial plants"

Reserch area: renewable sources, hydro power plant, small hydropower

Publications: 129

ORCID: 0000-0003-2838-6032

Contacts: tel./fax:+38(044)206-28-09

e-mail: hydro@ive.org.ua

Перелік використаних позначень та скорочень:

ГЕС - гідроелектростанція;

ГАЕС - гідроакумулювальна електростанція;

ДСТУ - державний стандарт України;

ВКУ - водний кодекс України;

Вступ. Сьогодні відновлення інтересу до малої гідроенергетики викликане невпинним зростанням тарифів на електроенергію, скороченням будівництва великих ГЕС та ГАЕС, значним підвищенням цін на органічне паливо та наявністю малоефективних

дизельних електростанцій у віддалених населених пунктах. Останніми роками питання розвитку малої гідроенергетики отримали підтримку на державному рівні у вигляді введення «зеленого» тарифу на вироблювану електроенергію, юридичного права на оренду та приватизацію існуючих малих гідроелектростанцій. Будівництво нових станцій затримується через наявність суб'єктивних і об'єктивних причин [1].

Подальший розвиток малої гідроенергетики неможливий без скоординованої державою схеми розміщення малих ГЕС, розробки процедур землевідведення, дозволів на спеціальне водокористування, налагодження співпраці 3 громадськими організаціями екологічного та природоохоронного спрямування, оновлення нормативної бази $[1,2]$. Чинна нормативна база не сприяє розвитку малої гідроенергетики, оскільки для виконання проєкту малих ГЕС (ГАЕС) необхідно затвердити таку саму кількість нормативної документації й висвітлити ті самі питання, що й для будівництва великої ГЕС (ГАЕС). Реформування потребує існуюча
ПУЕ - правила влаштування електроустановок; ГКД - галузевий керівний документ; ДБН - держані будівельні норми.

нормативно-технічна база проєктування, будівництва та експлуатації ГЕС та ГАЕС.

3 розвитком законодавчої бази України істотно зросла кількість прийнятих нормативноправових документів (законів, ДСТУ, постанов, указів, правил, норм, положень, інструкцій, методичних рекомендацій і т. ін.). Значна частина прийнятих документів містить в собі посилання на інші документи 3 описом внесених поправок в текст або скасуванням раніше діючих документів. Через велику кількість нормативно-правових документів, які вже розроблені та розробляються, законодавство України стало громіздким та заплутаним. Сприйняття загальної картини завдяки роботі 3 текстом документа $\epsilon$ трудомісткою процедурою. Крім того, існує ймовірність помилки при розробці нового документа, у разі, якщо не будуть враховані всі пов'язані з ним (раніше прийняті) документи, які так само мають аналогічний взаємозв'язок 3 іншими документами. Але в цілому процес розробки нових нормативних документів розвивається повільно, і в основному вирішуються нормативні завдання на відомчому рівні. Аналіз полегшує процедуру розгляду i моніторингу законодавчої бази, сприяе підвищенню ефективності роботи експертів, інженерів, науковців а також якості прийнятих законів у цілому. Практичне значення може мати потоковий аналіз існуючої законодавчої бази. 
Об'єкти соціальної сфери. Соціальна сфера - це сукупність галузей, підприємств, організацій, безпосереднім чином зв'язаних i таких, що визначають спосіб і рівень життя людей, їх добробут, споживання. Соціальна сфера життя суспільства являє собою систему, організовану для задоволення матеріальних i духовних людських потреб.

До основних об'єктів соціальної сфери належать:

1. Об'єкти обслуговування (гуртова та роздрібна торгівля, майстерні 3 ремонту автомобілів, побутових приладів, готелі та ресторани);

2. Транспорт (вантажний, пасажирський i спеціальний, а також зв'язок, складське господарство);

3. Фінансові установи (банки та їх відділення, страхові компанії, установи пенсійного забезпечення);

4. Освітні і виховні установи (дитячі сади, школи, гуртки за інтересами, коледжі, університети);

5. Заклади охорони здоров'я (лікарні, шпиталі, поліклініки, медичні центри, лабораторії);

6. Заклади культури (музеї, палаци i будинки культури, парки культури і відпочинку, цирки, театри, концертні зали, ботанічні сади, галереї) і спортивні установи (спортивні клуби, школи, секції, майданчики та стадіони).

Також до об'єктів соціальної сфери належать: об'єкти 3 надання комунальних та персональних послуг 3 розповсюдження інформації, діяльність 3 ведення приватних домашніх господарств.

Основні нормативні документи, що регламентують застосування гідроенергетичного обладнання, ресурсів та гідротехнічних споруд.

Оскільки на цей час їх існує дуже багато, і в одній статті їх розглянути практично не можливо, звернемо увагу на найважливіші:

- Водний кодекс України (ВКУ);

- Правила влаштування електроустановок (ПУЕ);
- Галузевий керівний документ (ГКД) 34.20.5072003. Технічна експлуатація електричних станцій і мереж. Правила;

- Галузевий керівний документ (ГКД) 34.03.1062003. Безпека гідротехнічних споруд i гідротехнічного обладнання електростанцій України. Положення про галузеву систему нагляду.

Ці документи наразі $\epsilon$ основою для створення (проєктування, спорудження, введення в експлуатацію) і функціонування (експлуатації) об'єктів гідроенергетики.

Розглянемо окремо та проаналізуємо нормативні документи, наведені вище.

Водний кодекс України набув чинності 20 липня 1995 року та складається 36 розділів, 24 глав і 112 статей.

Особливу увагу необхідно приділити таким статтям ВКУ [3]:

1. Стаття 66. Особливості спеціального водокористування та користування водними об'єктами для промислових і гідроенергетичних потреб.

Під час користування водними об'єктами для промислових потреб водокористувачі зобов'язані дотримувати встановлених умов спеціального водокористування, екологічних вимог, а також вживати заходів щодо зменшення витрат води (особливо питної) та припинення скидання забруднених зворотних вод шляхом удосконалення виробничих технологій, схем водопостачання та очищення стічних вод.

Гідроенергетичні підприємства зобов'язані дотримувати встановлених правил експлуатації водосховищ, режимів накопичення та спрацювання запасів води, режимів коливань рівня у верхньому i нижньому б'єфах та пропускання води через гідровузли, забезпечувати у встановленому порядку безперебійний пропуск суден, а також пропуск риби до місць нересту відповідно до проєктів рибопропускних споруд.

2. Стаття 77. Порядок експлуатації водосховищ.

Порядок експлуатації водосховищ визначається правилами, які затверджуються 
центральним органом виконавчої влади, що реалізує державну політику у сфері розвитку водного господарства, для кожного водосховища окремо, а для каскаду або системи водосховищ за погодженням 3 центральним органом виконавчої влади, що забезпечує формування державної політики у сфері охорони навколишнього природного середовища, i центральним органом виконавчої влади, що забезпечує формування державної політики у сфері санітарного та епідемічного благополуччя населення.

3. Стаття 80. Особливості користування малими річками.

3 метою охорони водності малих річок забороняється:

- змінювати рельєф басейну річки;

- руйнувати русла річок, струмків та водотоків, що пересихають;

- випрямляти русла річок та поглиблювати їхнє дно нижче природного рівня або перекривати їх без улаштування водостоків, перепусків чи акведуків;

- зменшувати природний рослинний покрив і лісистість басейну річки;

- розорювати заплавні землі та застосовувати на них засоби хімізації;

- проводити осушувальні меліоративні роботи на заболочених ділянках та в урочищах у верхів'ях річок;

- надавати земельні ділянки у заплавах річок під будь-яке будівництво (крім гідротехнічних, гідрометричних та лінійних споруд), а також для садівництва та городництва;

- здійснювати інші роботи, що можуть негативно впливати чи впливають на водність річки і якість води в ній.

Водокористувачі та землекористувачі, землі яких лежать в басейні річок, забезпечують здійснення комплексних заходів щодо збереження водності річок та охорони їх від забруднення i засмічення.

4. Стаття 82. Регулювання стоку річок, створення штучних водойм.

3 метою збереження екологічного та хімічного стану річок забороняється споруджувати в їх басейні водосховища і ставки загальним обсягом, що перевищує обсяг стоку даної річки в розрахунковий маловодний рік, який спостерігається один раз у двадцять років. Облік природоохоронних обмежень на використання стоку річки для виробництва електроенергії може бути реалізований при проведенні розрахункових досліджень за допомогою застосування ймовірнісних розподілів багаторічних витрат води $[4,5]$.

Створення на річках та у їх басейнах штучних водойм та водопідпірних споруд, що впливають на природний стік поверхневих і стан підземних вод, допускається лише 3 дозволу місцевих рад за погодженням 3 обласними, Київською, Севастопольською міськими державними адміністраціями, органом виконавчої влади Автономної Республіки Крим 3 питань охорони навколишнього природного середовища, центральним органом виконавчої влади, що реалізує державну політику у сфері розвитку водного господарства, і центральним органом виконавчої влади, що реалізує державну політику у сфері геологічного вивчення та раціонального використання надр.

Природоохоронні обмеження на використання гідроенергетичного ресурсу річки під час будівництва малих ГЕС можуть бути приведені до двох типів, а саме $[6,7,8]$ :

- обмеження на використання територій для будівництва малих ГЕС (національні природні парки, заповідники, пам'ятки природи, місця покладів корисних копалин і мінеральних вод, історико-культурні об'єкти, земельні ділянки спеціального призначення, значні площі затоплення);

- обмеження на використання води для виробництва електроенергії малою ГЕС (санітарний попуск, безперервне функціонування рибоходів, межень, повені та паводки, оперативні заходи 3 регулювання водного потоку через гідроспоруди, регулювання потужності ГЕС по водотоку).

Найповніше використання енергії водотоку річки досягається в результаті будівництва каскаду МГЕС при наявності сприятливого 
вертикального профілю i рельєфу місцевості вздовж течії [9].

Водним кодексом України регулюються відносини щодо збереження, науково обгрунтованого, раціонального використання вод для потреб населення та різних галузей економіки, охорони вод від забруднення, відтворення водних ресурсів, запобігання засміченню, шкідливим діям вод та усуненню їх наслідків, покращення стану водних об'єктів, а також охорони прав громадян, установ, підприємств, організацій на водокористування. Крім Водного кодексу, водні відносини регулюються Законом України «Про охорону навколишнього природного середовища» та іншими актами.

Правила улаштування електроустановок (ПУЕ) замовлено Міністерством енергетики та вугільної промисловості України; їх затверджено та надано їм чинності наказом від 21.07.2017 № 476. ПУЕ складаються із шести розділів, які в свою чергу поділені на глави, а останні - на параграфи і пункти.

Нова редакція ПУЕ враховує вимоги національних стандартів, будівельних норм i правил, галузевих нормативів та інших документів, які належать до предмету регулювання ПУЕ.

Категорії споживачів електроенергії. Згідно з ПУЕ всі споживачі електричної енергії поділяються на три категорії [10].

До першої категорії електропостачання належать найважливіші споживачі, перерва в електропостачанні яких може призвести до нещасних випадків, великих аварій, нанесення великої матеріальної шкоди через вихід з ладу цілих комплексів обладнання, взаємопов'язаних систем. До таких споживачів належать:

- гірничодобувна, хімічна промисловість та інші небезпечні виробництва;

- важливі об'єкти охорони здоров'я (реанімаційні відділення, великі диспансери, пологові відділення тощо) та інших державних установ;

- котельні, насосні станції першої категорії, перерва в електропостачанні яких призводить до виходу з ладу міських систем життєзабезпечення;
- тягові підстанції міського електрифікованого транспорту;

- установки зв'язку, диспетчерські пункти міських систем, серверні приміщення;

- ліфти, пристрої пожежної сигналізації, протипожежні пристрої, охоронна сигналізація великих будівель з великою кількістю людей, що перебувають у них.

Споживачі цієї категорії повинні підключатися від двох незалежних джерел живлення - двох ліній електропередачі. Найважливіші споживачі можуть мати третє незалежне джерело живлення для більшої надійності. Перерва в електропостачанні споживачів першої категорії дозволяється тільки на час автоматичного включення резервного джерела живлення.

Залежно від потужності споживача як резервне джерело електропостачання може виступати лінія електричної мережі, системи акумуляції енергії, дизельні генератори і т. ін.

До другої категорії постачання належать споживачі, при відключенні живлення яких зупиняється робота важливих міських систем, на виробництві виникає масовий брак продукції, є ризик виходу з ладу великих взаємопов'язаних систем, циклів виробництва.

Крім підприємств, до другої категорії електропостачання належать:

- дитячі заклади;

- медичні установи та аптечні пункти;

- міські установи, навчальні заклади, великі торгові центри, спортивні споруди, в яких може бути велике скупчення людей;

- всі котельні та насосні станції, крім тих, які належать до першої категорії.

Друга категорія електропостачання передбачає живлення споживачів від двох незалежних джерел. При цьому допускається перерва в електропостачанні на час, протягом якого обслуговчий електротехнічний персонал прибуде на об'єкт і виконає необхідні оперативні перемикання.

Третя категорія електропостачання споживачів включає в себе всіх споживачів, які не ввійшли в перші дві категорії. Зазвичай це 
невеликі населені пункти, міські установи, системи, перерва в електропостачанні яких не тягне за собою наслідків. Також до цієї категорії відносять багатоквартирні житлові будинки, приватний сектор, дачні та гаражні кооперативи.

Споживачі третьої категорії отримують електроенергію від одного джерела живлення. Перерва в електропостачанні споживачів цієї категорії переважно не більше доби - на час виконання аварійно-відновлювальних робіт.

Основна мета розділення споживачів на категорії - побудувати максимально ефективну мережу, яка, з одного боку, повинна здійснювати повною мірою потреби в електропостачанні всіх споживачів, задовольняти вимогам щодо надійності електропостачання, а 3 іншого - бути максимально спрощеною 3 метою оптимізації коштів на обслуговування і ремонт мереж.

Об'єкти соціальної сфери в основному належать до третьої категорії, але деякі з них, такі, як об'єкти охорони здоров'я, пристрої пожежної сигналізації, протипожежні пристрої, охоронна сигналізація великих будівель можуть бути віднесені до другої і навіть першої категорії. Тобто для таких категорій споживачів електроенергії необхідно передбачити резервні джерела. При цьому електропостачання треба розглядати в комплексі 3 урахуванням можливостей і доцільності технологічного резервування. Під час вирішення питань резервування слід ураховувати перевантажувальну здатність елементів електроустановок, а також наявність резерву в технологічному обладнанні. Також, згідно 3 параграфом 1.2.13 ПУЕ, під час вибору незалежних взаєморезервуючих джерел живлення, які є об'єктами енергосистеми, слід враховувати ймовірність одночасного залежного короткочасного зниження або повного зникнення напруги на період дії релейного захисту i автоматики в разі пошкоджень в електричній частині енергосистеми, а також одночасного тривалого зникнення напруги на цих джерелах живлення в разі важких системних аварій.

ГКД 34.20.507-2003. Технічна експлуатація електричних станцій і мереж.
Правила (далі - Правила). Цей нормативний документ затверджено та надано йому чинності Міністром палива та енергетики С.Ф. Срміловим 13 червня 2003 року. Він складається із 13 розділів та додатку. Наказом № 271 від 21 червня 2019 року Міністра енергетики та вугільної промисловості I. Насалика до цього нормативного документа внесені зміни, які викладені у новій редакції. Правила установлюють основні організаційні та технічні вимоги до експлуатації всіх об'єктів енергетики.

Розглянемо розділ 7, «Гідравлічні споруди, водне господарство i технічне водопостачання, гідравлічні установки». Основними вимогами цих Правил під час експлуатації гідротехнічних споруд (водопідпірні греблі й дамби, канали, тунелі, трубопроводи, водозабори і водоскиди, дамби золожужелевідвалів тощо), їхнього механічного устаткування (заслони і захисні загородження 3 їхніми механізмами) та гідротурбінних установок $є$ такі [11]:

- забезпечення справного стану;

- нормальна (безаварійна) робота;

- щоденне оперативне управління технічними пристроями гідровузла 3 метою створення запасу води та забезпечення нею водоспоживачів;

планування використання водних ресурсів;

- систематичні візуальні спостереження за станом споруд і догляд за ними;

проведення вимірювань відповідно до правил технічної експлуатації та інструкцій;

своєчасна обробка й аналіз отриманих даних спостережень і вимірювань;

- своєчасне виявлення дефектів, пошкоджень або аварійного стану споруд і обладнання;

розробка і здійснення заходів щодо приведення в належний технічний стан;

- удосконалення та реконструкція 3 метою підвищення надійності;

- визначення необхідності проведення спеціальних спостережень і досліджень;

виконання ремонтно-відновлювальних робіт; ведення технічної та експлуатаційної документації; 
- забезпечення охорони навколишнього середовища.

Необхідно відзначити, що під час експлуатації ГЕС та ГАЕС слід ураховувати потреби неенергетичних галузей народного господарства (об'єктів соціальної сфери) та вимоги охорони природи.

Для ГЕС 3 водосховищем комплексного використання має бути складений річний водогосподарський план, який встановлює щомісячні об'єми використання води різними водокористувачами. У разі наявності в енергокомпанії декількох ГЕС регулювання стоку повинно проводитися так, щоб одержати максимальний сумарний енергетичний ефект 3 урахуванням задоволення потреб інших водокористувачів. Також повинні бути узгоджені вимоги неенергетичних водокористувачів, що обмежують режими спрацьовування і наповнення водосховища, які мають бути включені в правила його експлуатації. Швидкість зміни витрати води через водоскидні споруди повинна визначатися місцевими умовами з урахуванням вимог безпеки населення i господарства в нижньому б'єфі гідровузла. Швидкість зміни витрат води через гідротурбіни не регламентується, і попередження про зміну витрат не робиться, якщо це не передбачено умовами експлуатації ГЕС.

Органи 3 регулювання використання й охорони вод встановлюють, 3 урахуванням перспективи розвитку, для кожного окремого водного об'єкта допустиму до скидання 3 продувними водами кількість шкідливих речовин, щоб гранично допустима концентрація міді $(\mathrm{Cu}+2)$ після змішування не перевищувала 0,01 мг/дм³ у воді водних об'єктів рибогосподарського призначення і 1,0 мг/дм³ - у воді водних об'єктів господарсько-питного i культурно-побутового водокористування.

$$
\text { Зараз }
$$

багато

високонапірних гідротехнічних споруд ГЕС та ГАЕС перебувають в експлуатації тривалий час. Для їх безпечної роботи після закінчення гарантійного терміну служби необхідно вжити низку заходів. Такі заходи мають базуватися на ряді спеціально розроблених нормативних галузевих керівних документів [12].

Дія цього документа поширюється на всі електростанції України (гідравлічні, гідроакумулювальні, атомні, теплові тощо), що будуються та експлуатуються, і є обов'язковою для всіх підприємств і організацій, які здійснюють проєктування, будівництво та експлуатацію гідротехнічних споруд i гідромеханічного обладнання електростанцій, а також виконують науково-дослідні, налагоджувальні, ремонтні та інші роботи, зокрема роботи 3 нагляду за безпекою цих споруд.

\section{ГКД 34.03.106-2003. Безпека} гідротехнічних споруд i гідротехнічного обладнання електростанцій України. Положення про галузеву систему нагляду. Документ затверджено наказом Міністра палива та енергетики України № 19821 квітня 2003 року. Документ складається 3 п'яти розділів. Він визначає завдання, функції та структуру галузевої системи нагляду за безпекою гідротехнічних споруд i гідромеханічного обладнання електростанцій України, тих, що будуються й тих, що експлуатуються, права та обов'язки ї учасників. Вимоги цього нормативного документа в основному повторюють положення попереднього, зокрема розділу 7 , щодо безпеки та нагляду за гідротехнічними спорудами i гідромеханічним обладнанням, але в більш розширеній формі [13].

Для проєктування, спорудження й експлуатації малих ГЕС та ГАЕС окремо не існує нормативно-правових документів, або якихось обмежень до їх розташування. У наш час розробка таких електростанцій повинна спиратися на чинну нормативну базу.

Висновки. Аналіз нормативних документів показав, що окремі стандарти мають дуже докладну деталізацію, а інші, навпаки, містять лише загальний опис. Для малих ГЕС та ГАЕС відсутні нормативні документи, які регламентують проєктування, спорудження й експлуатацію таких електростанцій, та створення обладнання на основі сучасних технологій i матеріалів для них. Для зміни ситуації 3 
вирішенням проблем розвитку малої гідроенергетики слід прийняти підзаконні акти, необхідні для функціонування системи державної підтримки відновлюваної енергетики; створити сучасну нормативну базу 3 державних будівельних норм (ДБН) і стандартів (ДСТУ) для проєктування, будівництва та експлуатації малих ГЕС та ГАЕС; створити пільгову систему оподаткування для виробників i споживачів енергетичного обладнання таких електростанцій; збільшити фінансову підтримку виконавців науково-дослідних і дослідно-конструкторських робіт в галузі відновлюваної енергетики.

Прийняті нормативні документи повинні бути доступними для розуміння користувачами й мати прозору структуру.

1. Васько П.Ф., Мороз А.В. Законодательные стимулы и природоохранные ограничения использования гидроэнергетических ресурсов малых рек Украины. Альтернативная энергетика и экология. 2014. № 15. С. 82-92.

2. Поташник C.I., Карамушка О.М. Безпечна експлуатація гідротехнічних споруд гідроелектростанцій України на сучасному етапі. Вісник Національного університету водного господарства та природокористування. 2013. № 2 (62). С. 11-19.

3. Водний кодекс України від 06.06.1995 p. № 213/92 - ВР.Відомості Верховної Ради України. 1995. № $24.189 \mathrm{c}$.

4. Васько П.Ф., Ибрагимова М.Р. Энергетическая эффективность малой гидроэлектростанции при экологических ограничениях на использование стока воды реки для производства электроэнергии. Альтернативная энергетика и экология. 2017. № 04-06 (216-218). С. 103-115. ISSN 1608-8298.

5. Vasko P., Verbovij A., Moroz A., Pazych S., Ibragimova M., Sahno L. Concept of Accumulation of Energy from Photovoltaic and Wind Power Plants by Means of Seawater Pumped Hydroelectric Energy Storage. 2019 IEEE 6th International Conference on Energy Smart Systems (ESS). Kyiv. Ukraine. 2019. Pp. 188-191. [Електронний ресурс]. https://doi.org/10.1109/ESS.2019.8764167. (дата звернення: 23.11.20).

6. Васько П.Ф., Мороз А.В., Бриль А.О., Ібрагімова М.P. Екологічні аспекти розвитку гідроенергетики в Україні. Відновлювана енергетика. 2018. № 2. C. $57-69$.

7. Бриль А.О., Васько П.Ф., Мороз А.В. Технічний потенціал гідроенергетичних ресурсів малих річок України з урахуванням природоохоронних обмежень. Гідроенергетика України. 2019. № 3-4. С. 47-51.
8. Васько П.Ф, Мороз А.В. Потенціал використання гідроенергетичних ресурсів основних малих річок України. Відновлювана енергетика. 2016. № 3. С. 50-56.

9. Васько П.Ф., Бриль А.О., Мороз А.В., Озорин Д.Ф. Расчёт теоретического значения гидроэнергетического потенциала малых рек с учётом обеспеченности стока воды. Альтернативная энергетика и экология. 2012. № 7. C. $126-132$.

10. Правила улаштування електроустановок. Офіц. вид. К. Міненерговугілля України. Київ. 2017. 617 с.

11. Технічна експлуатація електричних станцій i мереж. Правила: ГКД 34.20.507-2003. Офіц. вид. К. ГРІФРЕ. М-во палива та енергетики України. 2003. 598 с

12. Фаренюк Г.Г., Вайнберг О.I., Хлапук М.М., Шумінський В.Д. Надійність та безпека гідротехнічних споруд в умовах тривалої експлуатації. Наука та будівництво. 2019. № 20 (2). C. 4-18.

https://doi.org/10.33644/scienceandconstruction.v20i2.91

13. Безпека гідротехнічних споруд і гідротехнічного обладнання електростанцій: ГКД 34.03.106-2003. Офіц. вид. Х. Індустрія. М-во палива та енергетики України. 2003. $598 \mathrm{c}$.

\section{REFERENCE}

1. Vasko P.F., Moroz A.V. Zakonodatelnie stymulu i pryrodookhrannie ohranychenyia yspolzovanyia hydroэnerhetycheskykh resursov malykh rek Ukrainy. [Legislative incentives and environmental restrictions on the use of hydropower resources of small rivers of Ukraine]. Alternatyvnaia enerhetyka i ekolohyia. 2014. No. 15. Pp. 82-92. [in Russian].

2. Potashnyk S.I., Karamushka O.M. Bezpechna ekspluatatsiia hidrotekhnichnykh sporud hidroelektrostantsii Ukrainy na suchasnomu etapi. [Safe operation of hydraulic structures of hydroelectric power plants of Ukraine at the present stage]. Visnyk Natsionalnoho universytetu vodnoho hospodarstva ta pryrodokorystuvannia. 2013. No. 2 (62).

Pp. 11-19. [in Ukrainian].

3. Vodnyi kodeks Ukrainy vid 06.06.1995 r. № 213/92VR. [Water Code of Ukraine]. Vidomosti Verkhovnoi Rady Ukrainy. 1995. No. 24. 189 p. [in Ukrainian].

4. Vasko P.F., Ibrahymova M.R.. Enerhetycheskaia effektyvnost maloi hydroelektrostantsyy pry ekolohycheskykh ohranychenyiakh na ispolzovanye stoka vody reky dlia proyzvodstva elektroenerhyy. [Energy efficiency of a small hydroelectric power plant with environmental restrictions on the use of river water for electricity generation]. Alternatyvnaia enerhetyka i ekolohyia. 2017. No. 04-06 (216-218). Pp. 103-115. ISSN 1608-8298. [in Russian].

5. Vasko P., Verbovij A., Moroz A., Pazych S., Ibragimova M., Sahno L.. Concept of Accumulation of Energy from Photovoltaic and Wind Power Plants by Means of Seawater Pumped Hydroelectric Energy Storage. 2019 IEEE 6th International Conference on Energy Smart Systems (2019 IEEE ESS). April 17-19. 2019. Kyiv. Ukraine. Pp. 188-191. [Electronic resource]. https://doi.org/10.1109/ESS.2019.8764167. (Applying date: 23.11.20). [in English]. 
6. Vasko P.F., Moroz A.V., Bryl A.O., Ibrahimova M.R.. Ekolohichni aspekty rozvytku hidroenerhetyky $\mathrm{v}$ Ukraini. [Ecological aspects of hydropower development in Ukraine]. Vidnovluvana energetika. 2018. No. 2. Pp. 57-69. [in Ukrainian].

7. Bryl A.O., Vasko P.F., Moroz A.V. Tekhnichnyi potentsial hidroenerhetychnykh resursiv malykh richok Ukrainy z urakhuvanniam pryrodookhoronnykh obmezhen. [Technical potential of hydropower resources of small rivers of Ukraine taking into account environmental restrictions]. Hidroenerhetyka Ukrainy. 2019.No. 3-4. Pp. 47-51. [in Ukrainian].

8. Vasko P.F, Moroz A.V. Potentsial vykorystannia hidroenerhetychnykh resursiv osnovnykh malykh richok Ukrainy. [Potential for the use of hydropower resources of the main small rivers of Ukraine]. Vidnovluvana energetika. 2016. No. 3. Pp. 5056. [in Ukrainian].

9. Vasko P.F., Bryl A.O., Moroz A.V., Ozoryn D.F. Raschet teoretycheskoho znachenyia hydroenerhetycheskoho potentsyala malykh rek s uchetom obespechennosty stoka vody. [ Calculation of the theoretical value of the hydropower potential of small rivers, taking into account the availability of water flow].
Alternatyvnaia enerhetyka i ekolohyia. 2012. No. 7. Pp. 126-132. [in Russian].

10. Pravyla ulashtuvannia elektroustanovok. [Rules of arrangement of electrical installations]. Ofits. vyd. K. Minenerhovuhillia Ukrainy. Kyiv. 2017. 617 p. [in Ukrainian].

11. Tekhnichna ekspluatatsiia elektrychnykh stantsii i merezh. Pravyla: HKD 34.20.507-2003. [Technical operation of power plants and networks]. Ofits. vyd. K. HRIFRE. M-vo palyva ta enerhetyky Ukrainy. 2003. 598 p. [in Ukrainian].

12. Fareniuk H.H., Vainberh O.I., Khlapuk M.M., Shuminskyi V.D. Nadiinist ta bezpeka hidrotekhnichnykh sporud $\mathrm{v}$ umovakh tryvaloi ekspluatatsii. [Reliability and safety of hydraulic structures in conditions of long operation]. Nauka ta budivnytstvo. 2019. No. 20 (2). Pp.4-18.

https://doi.org/10.33644/scienceandconstruction.v20i2.91.

[in Ukrainian].

13. Bezpeka hidrotekhnichnykh sporud i hidrotekhnichnoho obladnannia elektrostantsii: HKD 34.03.1062003. [Safety of hydraulic structures and hydraulic equipment of power plants]. Ofits. vyd. Kh. Industriia. M-vo palyva ta enerhetyky Ukrainy. 2003. 598 p. [in Ukrainian]. 